\title{
Sewage Waste Water Characteristics and Its Management in Urban Areas- A Case Study at Pagla Sewage Treatment Plant, Dhaka
}

\author{
Masud Hassan 1, ", Rakib Hassan", Md Anik Mahmud", Husna Israt Pia ${ }^{1}$, Md Arafat Hassan ${ }^{2}$, \\ MJ Uddin ${ }^{1}$ \\ ${ }^{1}$ Department of Soil, Water and Environment, University of Dhaka, Dhaka, Bangladesh \\ ${ }^{2}$ Department of Geography and Environment, University of Dhaka, Dhaka, Bangladesh
}

Email address:

masudhassanswe1112@gmail.com (M. Hassan)

${ }^{*}$ Corresponding author

To cite this article:

Masud Hassan, Rakib Hassan, Md Anik Mahmud, Husna Israt Pia, Md Arafat Hassan, MJ Uddin. Sewage Waste Water Characteristics and Its Management in Urban Areas- A Case Study at Pagla Sewage Treatment Plant, Dhaka. Urban and Regional Planning.

Vol. 2, No. 3, 2017, pp. 13-16. doi: 10.11648/j.urp.20170203.11

Received: May 17, 2017; Accepted: June 3, 2017; Published: July 14, 2017

\begin{abstract}
The quick growth of the population, land use changed, and the industrial boom has carried huge problems of the environment of Dhaka city, Bangladesh especially on sewage waste water management. Waste treatment in developing countries like Bangladesh is a major anxiety and has become puzzling for various unfavorable conditions. Sewage Waste water management has a direct impact on the urban ecosystems, agriculture and river system. Insufficient education and little economic perspective are causing difficulties in implementing advanced treatment methods. Similar to other developing countries, Bangladesh is also facing numerous water-related problems in the urban region. The waste water of Dhaka city was collected and analyzed in the laboratory before and after the treatment. The present investigation was conducted to monitor the characteristic of the waste water, and its usability in different purposes like Irrigation, Aquaculture and drinking purposes. It is obvious from the results that, the current situation of treated water is not promising especially in N, P, Fe and Mn concentration for using as Aquaculture and Drinking Purposes. Although, the treated waste water can be used as Irrigation water and discharge into river without any further treatment.
\end{abstract}

Keywords: Sewage Waste Water Treatment, Physical \& Chemical Properties, Heavy Metals, Water Quality, Water Management

\section{Introduction}

Bangladesh is one of the most densely populated countries in the world. The population is almost about 160 million with a growth rate approaching $1.6 \%$. Dhaka is the capital of Bangladesh with the highest population density all over the world. Rapid growing urbanization in the capital is attracting people to the cities [2]. At present Dhaka has one sewage treatment plant which is Pagla sewage treatment plant (PST) in Pagla. The capacity of the plant is $120,000 \mathrm{~m}^{3} /$ day. The plant has 49,000 domestic sewer connections, $778 \mathrm{~km}$ of sewer line of different diameter, 20 sewer lift stations, 1 central pump station and 3 truck interceptor sewers. The treated effluent is discharged to the nearby river Buriganga [4].

As the topography of Dhaka is mostly flat gravity system is used. In this system, pipes are installed about $1 \mathrm{~m}$ from ground level carried to a depth of $6 \mathrm{~m}$ with a slope of about $0.66 \%$ accumulating the effluent in a sump. The effluent is lifted by pumps from the sump and discharged to an intake at $1 \mathrm{~m}$ depth from the ground surface and this process continues till the effluent reaches the treatment plant. The treatment plant was designed for a waste water with a BOD concentration of $200 \mathrm{mg} / \mathrm{L}$ and $\mathrm{SS}$ of $200 \mathrm{mg} / \mathrm{L}$. The treatment plant has also been designed for an effluent quality of $50 \mathrm{mg} / \mathrm{L}$ and $60 \mathrm{mg} / \mathrm{L}$ of BOD and SS respectively to release into the environment [4]. Waste water includes domestic waste water, consisting of black-water excreta, urine and associated sludge and grey water-kitchen and 
bathroom waste water or the mixture of domestic waste water from commercial establishments and institutions including hospitals with industrial waste water and run-off rain water [1]. In this study, Waste water includes urban waste water and sewage waste water. Sewage waste is mainly comprised of water $(99.9 \%)$ together with suspended and dissolved organic solids (carbohydrates, lignin, fats, soaps, synthetic detergents, synthetic organic chemicals from the process industries), inorganic solids including metals and also Pathogenic viruses and bacteria. The fact is that, these waste water may contain toxic substances and discharge of untreated waste water results in contamination of water bodies which is harmful in many ways. All kinds of variations in waste water use are possible and it is to be expected that different users will have different impacts on agricultural productivity, the environment, and human health. Appropriate policy decisions and technical interventions are likely to depend on the nature and characteristics of the waste water and the way in which it is being used [1]. On the other hand, providing safe and sufficient drinking water and proper sewerage system remains as the challenging tasks for Bangladesh. With the increasing scarcity of freshwater resources that are available to agriculture, the use of waste water in agriculture has increased, especially in arid and semi-arid countries. The major challenge is to optimize the benefits of waste water as a resource of both the water and the nutrients it contains, and to minimize the negative impacts of its use on human health.

\section{Objectives}

There had been few research was oriented by this area. Literature review reveals that the information regarding the study is very limited. Thus, an attempt was taken to assess the water quality before and after available all treatment and determine the usability of treated and untreated water for different purpose. In the present study an attempt was made to know the nature and composition of waste water in Dhaka city and the changes in the composition after treatment from Pagla sewage treatment plant. The aim of the present study was to investigate the physicochemical properties and concentration of certain metals viz., Cadmium, Iron and Manganese. In this study, tried to assess the treated waste water by its characteristics and compared with standard values for discharge in river and irrigation water quality. Irrigation with urban waste water is a fact of life in and around urban areas in many low-income countries. [4].

\section{Materials and Methods}

The waste water samples were collected from Pagla sewage treatment plant $\left(23^{\circ} 40^{\prime} 50.71^{\prime \prime} \mathrm{N}\right.$ and $\left.90^{\circ} 27^{\prime} 13.96^{\prime \prime} \mathrm{E}\right)$ installed at Pagla, which is $8 \mathrm{~km}$ away at the southeast of down town Dhaka city and approximately $1 \mathrm{~km}$ north from Buriganga. The site area of Pagla sewage treatment plant is 95.5 hectare. Waste water samples were collected before treatment from inlet and after treatment from outlet from
Pagla sewage treatment plant. The color and temperature of the samples were recorded carefully at the time of sampling while Samples were collected by plastic container and brought to laboratory carefully. For the analysis of physicochemical and heavy metals characteristics of influent and final effluent used some standard materials and methods. The $\mathrm{pH}$ of waste water samples determined in the laboratory directly by $\mathrm{pH}$ meter [5]. Dissolve Oxygen (DO) of waste water samples were measured by a portable DO meter and the test is performed on site [6]. Total Dissolved solid (TDS) was measured by TDS meter [6]. The Electrical conductivity (EC) of water samples measured in laboratory by Electrical conductivity meter [5]. Determination of total $\mathrm{N}$ is done by micro Kjeldahl's distillation method and total $\mathrm{P}$ is determined by spectrophotometer [5]. Phosphorus was determined by yellow color method [16].

Heavy metals (Iron (Fe), Manganese ( $\mathrm{Mn})$ and Cadmium (Cd)) of waste water samples from inlet (influent) and outlet (effluent) were measured directly by atomic absorption spectrophotometer (AAS) in the laboratory very carefully and at maximum sensitivity according to manufacturer's recommendations [6]. For the estimation of suspended solids (SS) the collected samples were centrifuged for 10 minutes at $10,000 \mathrm{rpm}$. The precipitations were taken in the porcelain cups and dried in an oven at $100^{\circ} \mathrm{C}$ till constant weight. Suspended solids were calculated by subtracting the initial weight from final weight.

\section{Results and Discussion}

The average temperature of water is ranges from 26.5 degree Celsius to 27.5 degree Celsius. The temperature of all treatment stage is more or less same. The color of waste water in influent water and water of primary sedimentation tank is brownish in color whereas sludge water is blackish in color. On the other hand, Lagoon water and Treated water is greenish in color. Similar result also found in others works $[3,18]$.

The values of physicochemical, nutrients and heavy metal parameters of sample of influent and effluent viz. $\mathrm{pH}$, DO, TDS, SS, EC, N, P, Fe, Mn, and Cd are shown in graph no-1. From graph no-1 we can observe the changes between untreated and treated waste water and Removal efficiency.

From the graph no 1, it has been clearly stated that the biggest changed found in cadmium concentration after all possible treatment at Pagla sewage treatment plant. The removal efficiency rate is high in EC, SS, Total N, P, and Fe. On the other hand, the changes of TDS, DO and Mn are not significant as others parameters does.

The $\mathrm{pH}$ is a measurement of presence of the amount of free hydrogen ions. A pH of 7 indicate that solution or water is neutral. Acidity increases as $\mathrm{pH}$ values decrease and alkalinity increases as $\mathrm{pH}$ values decrease. The $\mathrm{pH}$ of water affects the solubility of many toxic and nutritive chemicals and heavy metals. As acidity increases, most of the metals become more water soluble and more toxic [8]. The $\mathrm{pH}$ recorded in untreated waste water was 7.18 which is slightly 
basic. After final treatment it was 7.67 that designated that the treated waste water can be used as drinking, irrigation and aquaculture standard (Table 1). The ranges of $\mathrm{pH}$ is more or less slightly alkali in nature.

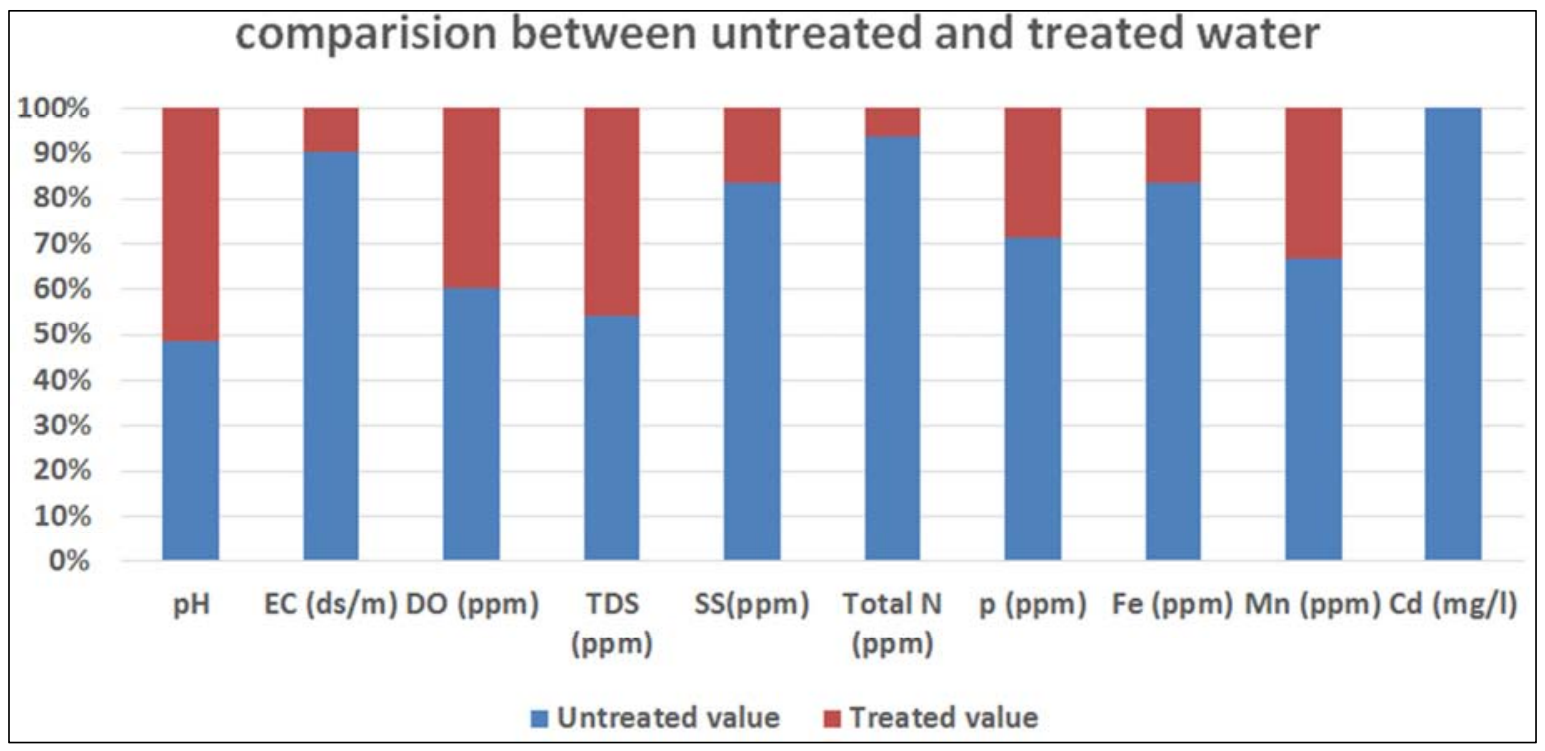

Figure 1. Compare between treated value (after treatment) and untreated value (before treatment) of Pagla sewage waste water treatment plant.

Electrical conductivity means the ability of a substance to conduct electricity. The electrical conductivity of water is related to the concentration of dissolved ions, increase in dissolved ions means increase in EC. It can serve as indicator for other water quality characteristics such as total dissolved solids (TDS). If the EC of a stream increase then it indicates that there is a source of dissolved ions. EC measurements can be used as a way to find water quality problem [7]. In the present study, the EC recorded in untreated waste water was $2.84 \mathrm{ds} / \mathrm{m}$. After final treatment it was $0.31 \mathrm{ds} / \mathrm{m}$ which imply the treated waste water can be used as Drinking and Aquaculture standard but not for irrigation purposes on the basis of EC (Table 1). The removal efficiency of EC is around $89.0 \%$ at Pagla sewage treatment plant.

Dissolved oxygen refers to the level of free, noncompound oxygen present in water or other liquids. It is an important parameter in assessing water quality because of its influence on the organisms living within a body of water. Oxygen gets into water by diffusion from the surrounding air, by aeration (rapid movement) whether natural or man-made, and as a waste product of photosynthesis. A dissolved oxygen level that is too high or low can harm aquatic life and affect water quality [9]. The DO recorded in untreated waste water is $6.39 \mathrm{mg} / \mathrm{l}$. After final treatment it was $4.20 \mathrm{ppm}$ that can be usable at almost all way on the basis of DO (Table 1). The removal efficiency of DO is around $34.2 \%$ at Pagla sewage treatment plant.

Suspended solids (SS) is an indicator of water quality which refers to the small solid particles in the water. The untreated and treated values of SS is 124.72 and 24.48 respectively. The treated values of SS could be uses as agriculture purposes but not in drinking Purposes.

Table 1. Water quality standard for different purposes with treated values.

\begin{tabular}{lllll}
\hline Parameter & Irrigation Standard(15, 17) & Aquaculture Standard(13, 14 ) & Drinking Water Standard(12) & Treated values \\
\hline $\mathrm{pH}$ & $6.50-8.50$ & $6.50-8.50$ & $6.5-8.5$ & 6.51 \\
$\mathrm{EC}(\mathrm{Us} / \mathrm{m})$ & $0.00-3.00$ & 0.19 & 0.30 & 0.31 \\
$\mathrm{DO}(\mathrm{ppm})$ & 5.00 & 5.00 & 4.00 & 4.20 \\
TDS(ppm) & $0.00-2000$ & 120 & 500 & 420 \\
Total N (ppm) & $0.00-30.00$ & 0.10 & 1.00 & 5.10 \\
$\mathrm{P}(\mathrm{ppm})$ & $0.00-2.00$ & 0.10 & $\mathrm{n} / \mathrm{a}$ & 9.80 \\
$\mathrm{Cd}(\mathrm{ppm})$ & 0.01 & $0.20-1.80$ & 0.002 & 0.00 \\
$\mathrm{Fe}(\mathrm{ppm})$ & 5.00 & 0.15 & 0.07 & 1.55 \\
$\mathrm{Mn}(\mathrm{ppm})$ & 0.20 & 0.01 & 0.02 & 0.15 \\
\hline
\end{tabular}

Nitrogen and phosphorus are essential nutrient for the growth of algae and other aquatic plants. Aquatic life is dependent upon these nutrients which usually occur in low level in surface water. Total nitrogen and total phosphorus are the most important factor for all kind of biological organisms but quantities can be excessive and if the concentration is high then it can boost up algae growth and aquatic plant [8, 10]. The total Nitrogen and Phosphorus were measured in untreated waste water was 76.30 and $4.50 \mathrm{ppm}$. After final treated it were 5.10 and $1.80 \mathrm{ppm}$ which imply that the treated waste water can be used only irrigation purpose but not for Drinking and Aquaculture on the basis of Nitrogen and phosphorous. (Table-1). The removal efficiency of Nitrogen and Phosphorous are $93.3 \%$ and $60.0 \%$ respectively at Pagla sewage treatment plant.

The heavy metals are at very low concentrations in the 
environment and they are typically introduced to surface waters as waste from human activities or natural. Many of this metals are necessary for the growth of biological life but only in trace concentrations, but if the required concentrations are exceeded they can become toxic and thus interfere with the potential beneficial uses waste water [11]. The content of $\mathrm{Fe}, \mathrm{Mn}$ and $\mathrm{Cd}$ recorded in untreated waste water was $7.74,0.30,0.17 \mathrm{ppm}$ respectively. After treatment, the treated waste water contains $1.55,0.155$ and $0.00 \mathrm{ppm}$ respectively. The studied results shows that- for $\mathrm{Cd}$ and $\mathrm{Mn}$, treated water be used as drinking, Irrigation and aquaculture standard whereas for Fe, the treated waste water cannot use as drinking and Aquaculture standard but can be used as Irrigation Purpose (Table 1). The removal efficiency of Fe, $\mathrm{Mn}$, and Cd are $79.9 \%, 50.0 \%$ and $100 \%$ respectively at Pagla sewage treatment plant.

\section{Conclusion}

From the above discussion, it has been clear that, the treated water can be used as Irrigation purposes without any further treatment because all standard values for irrigation are justify with treated values. Additionally, the treated water also can be used as aquaculture by treating for modification of TDS, N, P, Fe and Mn. Furthermore, the treated water can be used as drinking water by reducing $\mathrm{N}, \mathrm{Fe}$, and Mn content of treated waste water. Therefore as per the results, it is suggested that the effluent should be pretreated before disposing into the environment. In addition there is an urgent need to improve their efficiency rate by Including advanced tertiary treatment processes such as rapid sand filtration, UV disinfection, chlorination, effluent polishing, construction of artificial wetlands etc. That's why further treatment are necessary for using the studied water as a drinking and aquaculture purposes by implication of modern method and technology.

\section{References}

[1] Van der Hoek, W., et al., 2004. A Frame Work for a Global Assessment of the Extent of Waste water Irrigation: The Need for a Common Waste water Typology. International Water Management Institute (IWMI), Bierstalpad.

[2] CIA (2016) Central Intelligence Agency, United Sates of America, The World Fact book. [Online] Available at: https://www.cia.gov/library/publications/theworldfactbook/geos/bg.html [Accessed 14 May 2016].
[3] Kumar N. J. and Krishnamoorthi, K. P. (1983) Evaluation of toxicity of ammoniacal fertilizer Effluents. Environ. Pollution series A, Ecological and Biological. 30: 76-86.

[4] Haq A. K., (2006) Water management in Dhaka. Water Resources Development, 22(2), pp. 291-311.

[5] Jackson, M. L. (1967) Soil Chemical Analysis, Prentice Hall, Inc. Englewood Cliffs, N. J. USA, pp. 227-261.

[6] Page A. L., Miller R. H. and Keeney D. R. (1982) Methods of Soil Analysis (ed.), Part 2. Am. Soc. Agron. Soil Sci. Am. Madison, Wis. USA, pp. 159-446.

[7] Brady N. C. and Well R. R. (2002) the Nature and Properties of Soils. $13^{\text {th }}$ ed. Pearson Education, Inc. New Delhi, India, pp. 261-269.

[8] Asano T., Burto F. L., Leveren H. L., Suchihashi R. and Tchobanoglous G. (2003) "Waste water Engineering Treatment and Reuse," 4th Edition, McGraw Hill, New York, 2003.

[9] Peavy H. S., Rowe D. R. and Tchobanoglous, G (1985). Environmental Engineering. McGraw Hill, New York, pp. 1456.

[10] Pescod, M. B. (1992). Waste water Treatment and Use in Agri-culture. Food and Agriculture Organization (FAO) Irrigation and Drainage Paper, p. 73.

[11] Lester J. (1987) Heavy Metals in Waste water and Sludge Treatment Process. CRC Press, Inc., Boca Raton, pp. 1-40.

[12] WHO Guidelines for drinking water Quality, set up in Geneva, 1993, are the international reference point for standard setting and drinking water safety.

[13] Davis J. (1993). Survey of Aquaculture effluents permitting and 1993 standards in the South. Southern Regional Aquaculture Centre, SRAC publication no 465 USA, 4PP.

[14] Water quality standards for coastal waters marine outfallsepa, 1986 [GSR 7, dated Dec. 22, 1998.

[15] Imamul Huq S. M., and Alam M. D. (2005). A Handbook on Analyses of Soil, Plant and Water. BACER-DU, University of Dhaka, Bangladesh, 246pp. 239.

[16] Page A. L. (1982). Methods of Soil Analysis(Ed). Part 2. Am. Soc. Agron-Soil Sci. Soc, Am. Madison. Wis U.S.A. pp. 159575 .

[17] FAO (1985). Water Quality for Agriculture. Food and Agriculture Organization, Rome, Italy.

[18] Lloyd R. (1992). Pollution and Freshwater fish. Blackwell Scientific Publications Ltd. pp. 3-75. 